\title{
DOI: https://doi.org/10.35546/kntu2308-8834/2020.1.15
}

\section{УДК 35.351}

\section{Криштанович Мирослав Франкович}

професор кафедри педагогіки та інноваційної освіти Національного університету «Львівська політехніка», доктор наук $з$ державного управління, професор

\section{Криштанович Світлана Володимирівна}

доцент кафедри економіки та менеджменту Львівського державного університету фізичної культури ім. Івана Боберського, кандидат наук з державного управління, доцент

\section{МЕХАНІЗМИ ДЕРЖАВНОГО УПРАВЛІННЯ ЩОДО ОРГАНІЗАЦІЇ СИСТЕМИ ЗАБЕЗПЕЧЕННЯ ПОЛІТИЧНОЇ БЕЗПЕКИ ДЕРЖАВИ}

Політична безпека є ключовою складовою політики державної безпеки. Утрата політичного контролю з боку суспільства або його невідповідність можливостям та інтересам суспільства неминуче призводять до його деградаиії. Тому проблема забезпечення політичної безпеки України особливо актуальна для державної політики, оскільки ї̈ значною мірою зосереджено в політичній сфері через наявні виклики та загрози. Ї̈ рішення для влади та суспільства є пріоритетними й потребують серйозної уваги до иієї сфери, оскільки життєздатність суспільства та держави залежить від рівня їх безпеки.

Однією із головних $і$ пріоритетних вимог до системи політичної безпеки $\epsilon$ легітимність та законність ї̈ функціонування. Важливою є законодавча база, щзо створює єдину правову базу для вирішення питань політичної безпеки, сприяє впорядкованості політичних інтересів держави, державних установ та окремих осіб, а також їх перетворенню на гармонійну загальнодержсавну систему інтересів.

Таким чином, державну політику спрямовано на оптимальне функціонування системи політичної безпеки як складової національної безпеки, вона може повністю сприяти поліпшенню якості та ефективності ї̈ функціонування, значно стимулюватиме прочес забезпечення політичної безпеки при ухваленні певних адміністративних рішень щзодо реалізачії політичних інтересів національної безпеки. Лише за таких обставин вона зможе надати пріоритет реалізачіі національних інтересів; взаємопов'язаність і збалансованість усіх компонентів політичної безпеки; недоторканність конституційних прав і свобод усіх громадян; постійне підтримання високого рівня професіоналізму суб'єктів системи політичної безпеки відповідно до вимог до якості їх підготовки до міжнародних стандартів у цій галузі; а також абсолютна перевага раціональної та превентивної безпеки.

Політична безпека займає ключове місие в системі національної безпеки і постає одним із ї̈ основних структурних елементів. Це пояснюється всебічним характером $i$ життєво важливим значенням політичної сфери для існування держави й суспільства, а також функиіонування основних сочіальних інститутів та організацій.

Ключові слова: механізми державного управління, політична безпека, держава, сучасне управління, органи державної влади. 
Постановка проблеми в загальному вигляді. Політична безпека займає ключове місце в державній політиці із надання безпеки. Утрата суспільством політичної керованості або їі невідповідність можливостям і інтересам суспільства неминуче ведуть до його деградації. Саме тому проблема забезпечення політичної безпеки України є особливо актуальною для державної політики, оскільки їі значною мірою через наявні виклики й загрози зосереджено саме в політичній сфері. Її вирішення для влади i суспільства є пріоритетними і вимагають серйозної уваги до цієї сфери, адже життєспроможність суспільства i держави залежить від рівня їх безпеки.

Аналіз останніх досліджень і публікацій. У сучасній Україні питання політичної безпеки досліджували вітчизняні учені, такі як М. Орел, Г. Ситник, О. Пошедін, М. Шевченко В. Кремень, І. Бінько, С. Головащенко В. Тертий О. Кравчук, Д. Кучма та інші. Однак питання, які нас цікавлять, не до кінця вивчено. Ми хочемо продовжити це дослідження 3 проблеми загальних концептуальних основ i окремих аспектів розроблення конкретної політичної безпеки на певний проміжок часу.

Виділення не вирішених раніше частин загальної проблеми. Головне призначення системи забезпечення політичної безпеки полягає в організованій державою взаємодії суб’єктів державних органів, громадських організацій, посадових осіб та окремих громадян, об'єднаних цілями та завданнями щодо захисту інтересів і гарантування в Україні безпеки особи, суспільства та держави від внутрішніх і зовнішніх загроз в усіх сферах їх життєдіяльності.

Формулювання цілей статті. Метою статті $\epsilon$ дослідження функціонування системи забезпечення політичної безпеки держави та створення достатніх умов щодо їі діяльності. 
Виклад основного матеріалу. Насамперед зазначимо, що система політичної безпеки будь-якої країни має вирішувати досить суперечливе завдання: 3 одного боку - надійно захищати політику, яка відповідає національно-державним інтересам, а 3 іншого - виключити іï збитковий i небезпечний для національно-державних інтересів процес. Вітчизняні науковці під системою забезпечення політичної безпеки пропонують розуміти «законодавчо визначені інститути (суб’єкти), засоби та процедури за допомогою яких забезпечується реалізація політичних інтересів людини, суспільства та держави» або елементи цієї системи, «які забезпечують безпеку політичної системи держави від деструктивних впливів внутрішнього та зовнішнього походження» [1, с. 360].

Сучасне управління системи забезпечення політичної безпеки базується на сукупності вже чинних і спеціально створених органів, державних і недержавних структур, соціальних груп, суспільних об’єднань і громадських організацій, окремих осіб, а також специфічних правових, інформаційних, політичних, економічних та інших зв'язків між ними. Вона зумовлюється високою значущістю влади, держави і політики як чинник благополуччя країни, народу та громадян [2].

Основними складовими сучасної системи забезпечення політичної безпеки України є:

- державно-управлінська складова, що забезпечує ефективне функціонування державної влади та системи управління органами державної влади на різних рівнях;

- суспільно-політична складова, у структурі якої виявляються та забезпечуються політичні інтереси окремих груп, громадян і суспільства загалом, забезпечуються їх соціально-політичні права;

- суспільно-конфліктологічна складова, що забезпечує ненасильницьке розв’язання внутрішніх суспільних конфліктів; 
- ідеологічно-інформаційна складова, що базується на ідеологічному, соціально-психологічному та інформаційному забезпеченні суспільнополітичної стабільності [3].

Вони сукупно становлять собою систему взаємопов'язаних i взаємозумовлених суб'єктів забезпечення політичної безпеки, що на основі чинного законодавства трансформуються в політику національної безпеки та в заходи політичного, воєнного та іншого характеру.

Основними механізмами забезпечення політичної безпеки, на які спрямовуються державно-управлінські впливи суб’єктів ії забезпечення, є:

- конституційно-правові засади суспільного устрою;

- конституційні права і свободи людини та громадянина;

- інститути (складові) політичної системи;

- чинники (суб'єкти, процеси тощо), які породжують загрози політичній безпеці.

Однією із головних і пріоритетних вимог до системи забезпечення політичної безпеки $є$ легітимність і законність іï функціонування. Істотного значення набуває відповідна законодавча база, що створює єдине правове поле для вирішення питань політичної безпеки, сприяє впорядкуванню політичних інтересів держави, громадських інституцій та особистостей, а також перетворенню їх на гармонійну загальнонаціональну систему інтересів [4].

Забезпечення політичної безпеки України здійснюються 3 урахуванням низки принципів. Основними з них можна вважати:

- дотримання суб’єктами й об'єктами безпеки Конституції України та українського законодавства;

- чітке розмежування повноважень та взаємодія органів державної влади в забезпеченні політичної безпеки;

- демократична спадкоємність системи правління та політичного режиму; 
- єдність, взаємозв'язок і збалансованість політичної безпеки 3 іншими видами національної безпеки;

- своєчасність, комплексність та адекватність заходів забезпечення політичної безпеки України;

- суспільна стабільність і громадська злагода;

- цілісність і збалансованість системи політичної безпеки, іiі інтегрованість у систему національної безпеки;

- збереження балансу політичних інтересів особи, суспільства, держави [5, с. 74].

Основними функціями системи забезпечення політичної безпеки країни є:

- регулювання взаємовідносин між суб’єктами забезпечення політичної безпеки;

- координація діяльності суб’єктів забезпечення політичної безпеки;

- забезпечення політичної безпеки суспільства і людини, визначення їх прав, обов'язків і відповідальності;

- установлення порядку застосування засобів забезпечення політичної безпеки;

- реалізація політичних інтересів особи та соціальних груп, зокрема опозиції, через формування демократичної системи політичних інститутів;

- організаційне забезпечення ефективного функціонування механізму співпраці органів державної влади 3 громадськими організаціями.

Зазначимо, що означені функції системи забезпечення політичної безпеки, як органічна складова цілісної системи національної безпеки України, реалізують політичні інтереси як держави, так і суспільства, громадськості, особи. При цьому розроблення та затвердження головних завдань i напрямків забезпечення політичної безпеки $є$ функцією найвищого політичного керівництва держави. Тільки на такому рівні 3 
урахуванням усіх реалій зовнішньої та внутрішньо політичної ситуації може бути чітко сформульовано головні завдання, форми й способи їх реалізації.

Основними завданнями системи забезпечення політичної безпеки Української держави є:

- обгрунтування вимог щодо реалізація державної політики у сфері національної безпеки;

- захист конституційних прав, свобод та інтересів громадян України;

- прогнозування, передбачення й ідентифікація реальних i потенційних політичних і інших загроз;

- моніторинг, надання суб'єктам цієї системи потрібних відомостей про стан об'єктів системи забезпечення політичної безпеки, про характер та ступінь деструктивних і дестабілізаційних дій;

- організація профілактичної роботи, спрямованої на попередження та нейтралізацію причин можливих політичних загроз на можливо ранній стадії їх зародження і розвитку;

- мобілізаційна діяльність, що передбачає здатність усієї системи до оперативного реагування на загрози, своєчасного залучення необхідних сил і засобів [6].

Здійснення цих завдань буде ефективним, якщо воно буде спиратися на виконавчі структури з раціональним розподілом і координацією їх дій. Це дасть змогу відпрацювати та ефективно реалізовувати визначену державну політику, забезпечити захист інтересів держави, суспільства і громадян, сприятиме досягненню суспільної стабільності та громадської злагоди [7].

Важливу роль для політичної безпеки відіграє найбільш сприятливе, оптимальне функціонування системи iї забезпечення. Як уважає О. Кравчук, основними шляхами вдосконалення системи забезпечення політичної безпеки України мають бути: 
- розроблення й ухвалення стратегії політичної безпеки, політичних, економічних, соціальних і інших довгострокових програм, скерованих на забезпечення конкретних видів національної безпеки (зокрема політичної);

- своєчасне внесення до нормативно-правових документів змін і доповнень 3 метою їх відповідності міжнародному стану;

- ініціювання, формування, реалізація й оцінювання державної політики з реальним, а не декларативним віддзеркаленням у ній інтересів особи, суспільства і складових його соціальних груп, а також держави;

- удосконалення організаційної структури системи забезпечення національної безпеки та її політичної складової;

- підвищення ефективності діяльності суб’єктів забезпечення політичної безпеки України;

- пошук i вибір раціональних рішень для комплексного використання наявних можливостей і ресурсів у системі забезпечення політичної безпеки країни [8,с. 118].

Висновки 3 даного дослідження. Таким чином, державна політика, що спрямована на оптимальне функціонування системи забезпечення політичної безпеки як складової національної безпеки, повною мірою зможе сприяти підвищенню якості та ефективності iï функціонування, значною мірою стимулюватиме процес забезпечення політичної безпеки при ухваленні певних управлінських рішень із питань реалізації національних політичних інтересів.

Перспективи подальших розвідок. Лише за таких умов така політика, на нашу думку, зможе забезпечити пріоритет у реалізації національних інтересів; взаємозв'язок і збалансованість усіх складових політичної безпеки; непорушність конституційних прав і свобод усіх громадян; постійне підтримання високого рівня професіоналізму суб'єктів системи забезпечення політичної безпеки згідно з вимогами до якості їх 
підготовки та відповідності міжнародним стандартам у цій сфері; а також безумовним наданням переваг раціональній та превентивній безпеці.

\section{СПИСОК ВИКОРИСТАНИХ ДЖЕРЕЛ:}

1. Государственное управление в сфере национальной безопасности: словарьсправочник / состав.: Г.П. Сытник, В.И. Абрамов, В.Ф.Смолянюк и др.; под общ. редакцией Г.П. Сытника. К. НАДУ, 2012.496 с.

2. Орел М.Г. Політична безпека як наукова категорія та мета системи державного управління у сфері політичної безпеки. Держава та регіони. Серія: Державне управління: Науково-виробничий журнал / за ред. О.В. Покатаєвої. Запоріжжя: КПУ, 2017. № 2 (58). С. 11-16.

3. Політико-ідеологічний процес в українському суспільстві в умовах модернізації: порівняльний аналіз : монографія / за заг. ред. Ф. М. Рудича. К.: IПіЕНД ім. І.Ф. Кураса НАН України, 2013. 448 с.

4. Кравчук О.Ю. Створення системи забезпечення політичної безпеки України в межах цілісної політики національної безпеки. Наукові праці з державного управління. 2010. Том 131. Випуск 118. С.73-76.

5. Косілова О.І. Політична безпека в системі національної безпеки України. Правова інформатика. 2011. № 1(29). С.72-78.

6. Політична безпека України: концептуальні засади та система забезпечення: монографія / В.Г. Кремень, І.Ф. Бінько, С.І. Головащенко. К. МАУП, 1998. 92 с.

7. Тертий В. Пошуки i шляхи розв'язання політичної безпеки. Безпека життедіяльності. 2009. № 1. С. 27-29.

8. Кравчук О.Ю. Актуальні аспекти політичної безпеки в сучасних українських реаліях. Молодий вчений. 2015. № 5 (20). С. 115-121.

\section{ANNOTATION}

Kryshtanovych Miroslav. Professor of the Department of Pedagogy and Innovative Education Lviv Polytechnic National University, Doctor of Science in Public Administration, Professor

Kryshtanovych Svitlana. Associate Professor of Economics and Management Lviv State University of Physical Culture them. Ivan Bobersky, Candidate of Sciences in Public Administration, Associate Professor

MECHANISMS OF PUBLIC ADMINISTRATION FOR 
Political security is a key part of state security policy. Loss of political control by society or its inappropriateness to society's capabilities and interests inevitably lead to its degradation. Therefore, the problem of ensuring the political security of Ukraine is particularly relevant to public policy, since it is largely concentrated in the political sphere because of the existing challenges and threats. Its decisions for the authorities and society are priorities and require serious attention to this area, since the viability of society and the state depends on the level of their security.

One of the main and priority requirements for the political security system is the legitimacy and legitimacy of its functioning. A relevant legal framework is essential, which creates a single legal framework for resolving political security issues, facilitates the ordering of political interests of the state, public institutions and individuals, as well as their transformation into a harmonious nation-wide system of interests.

Thus, public policy aimed at the optimal functioning of the political security system as a component of national security can fully contribute to improving the quality and efficiency of its functioning, will greatly stimulate the process of ensuring political security in making certain administrative decisions on the implementation of national security political interests. Only in such circumstances will it, in our opinion, be able to give priority to the realization of national interests; the interconnectedness and balance of all political security components; inviolability of the constitutional rights and freedoms of all citizens; constant maintenance of a high level of professionalism of the subjects of the political security system, in accordance with the requirements for the quality of their preparation to international standards in this field; as well as the absolute preference for rational and preventive security.

Political security occupies a key place in the national security system and acts as one of its main structural elements. This is due to the overarching nature 
and vital importance of the political sphere for the existence of the state and society, as well as the functioning of major social institutions and organizations.

Key words: mechanisms of public administration, political security, state, modern administration, public authorities.

\section{References:}

1. Hosudarstvennoe upravlenye $\mathrm{v}$ sfere natsyonal'noy bezopasnosty: slovar'-spravochnyk / sostav.: H.P. Sytnyk, V.Y. Abramov, V.F.Smolyanyuk y dr.; pod obshch. redaktsyey H.P. Sytnyka.K. NADU, 2012.496 s.

2. Orel M.H. Politychna bezpeka yak naukova katehoriya ta meta systemy derzhavnoho upravlinnya u sferi politychnoyi bezpeky. Derzhava ta rehiony. Seriya: Derzhavne upravlinnya: Naukovo-vyrobnychyy zhurnal / za red. O.V. Pokatayevoyi.Zaporizhzhya: KPU, 2017.№ 2 (58).S. 11-16.

3. Polityko-ideolohichnyy protses $\mathrm{v}$ ukrayins'komu suspil'stvi v umovakh modernizatsiyi: porivnyal'nyy analiz : monohrafiya / za zah. red. F.M. Rudycha.K.: IPiEND im. I.F. Kurasa NAN Ukrayiny, 2013.448 s.

4. Kravchuk O.YU. Stvorennya systemy zabezpechennya politychnoyi bezpeky Ukrayiny $\mathrm{v}$ mezhakh tsilisnoyi polityky natsional'noyi bezpeky. Naukovi pratsi z derzhavnoho upravlinnya. 2010. Tom 131. Vypusk 118.S.7376.

5. Kosilova O.I. Politychna bezpeka v systemi natsional'noyi bezpeky Ukrayiny. Pravova informatyka.2011. № 1(29).S.72-78.

6. Politychna bezpeka Ukrayiny: kontseptual'ni zasady ta systema zabezpechennya: monohrafiya / V.H. Kremen', I.F. Bin'ko, S.I. Holovashchenko. K. MAUP, 1998. 92 s.

7. Tertyy V. Poshuky i shlyakhy roz"yazannya politychnoyi bezpeky. Bezpeka zhyttyediyal'nosti. 2009. № 1. S. 27-29. 

місцевого самоврядування 2020 № 1

8. Kravchuk O.YU. Aktual'ni aspekty politychnoyi bezpeky v suchasnykh ukrayins'kykh realiyakh. Molodyy vchenyy. 2015. № 5(20). S.115121. 